\begin{tabular}{|l|c|c|}
\hline \multicolumn{2}{|c|}{ DJS Vol. 38 (2017) 183-193 } \\
\hline $\mathbf{1 9 6 9}$ & Delta Journal of Science & \\
\hline Research Article & Available online at & \\
\hline
\end{tabular}

\title{
A Spectroscopic and Photochemical Behavior of Some Coumarin Derivatives
}

\author{
Mohamed.Y. El-Sheikh, Saleh. A. Azim, Ali. K. Abou Saif and Ehab. A. Okba* \\ Chemistry Department, Faculty of Science, Tanta University, Tanta, Egypt
}

\begin{abstract}
The electronic absorption, emission spectra as well as fluorescence quantum yields of some coumarin derivatives were measured in different solvents of different polarities. $\mathrm{pKa}$ and $\mathrm{pKa}^{*}$ were calculated using universal buffers.

The dyes undergo micellization in different micelles and may be used as a probe to determine the critical micelle concentrations (CMC) of CTAB and SDS. The effect of metal ions like $\left[\mathrm{Cu}^{+2}, \mathrm{Co}^{+3}, \mathrm{Ni}^{+2}\right]$ as quenchers and the effect of temperature on quenching are studied and thermodynamic parameters have been calculated.
\end{abstract}

Key words: fluorescence quantum yield, coumarin derivatives, metal ion quencher

*(Corresponding author)

\section{Introduction:}

Coumarin (1, 2-benzopyrone or phenylpropanoids) and its derivatives are widely distributed throughout nature and many exhibit useful and diverse biological activities [1, 2$]$. Coumarins occur as secondary metabolites in the seeds, roots and leaves of many plant species, notably in high concentration in the tonka bean and thus the name comes from a French word, coumarou, for the tonka bean.

Their function is far from clear, although suggestions include plant growth regulations, fungistasis, bacteriostasis and, even, waste products [3]. Some naturally occurring coumarin derivatives include warfarin, umbelliferone (7hydroxycoumarin, aesculetin (6,7dihydroxycoumarin), herniarin (7methoxycoumarin, psoralen and imperatorin. Now the diversity of coumarin derivatives, both natural and synthetic, has grown and are thus divided into several subclasses. Most reviews classify coumarins according to whether particular compounds are simple coumarins (e.g. coumarin, and limettin), linear furanocoumarins (e.g. imperatorin, 7 and isopimpinellin, angular furanocoumarins (e.g. angelicin), linear pyranocoumarins (e.g. xanthyletin) or angular pyranocoumarins (e.g. seselin) [4]. Murray et al. [5], however, used a biogenetic approach based upon the number of nuclear oxygen atoms in classifying coumarin-containing compounds.

Coumarin derivatives have been found to have numerous therapeutic applications including photo chemotherapy, antitumor and anti-HIV therapy [ $\underline{6}$, 7], and as central nervous system (CNS) stimulants [8], antibacterial [9, 10] antiinflammatory [11], anti-coagulants [12] and dyes [13]. In addition, coumarins are known to be lipid lowering agents with moderate triglyceride lowering activity [14]. Furthermore, hydroxycoumarins are powerful chain-breaking antioxidants and can prevent free radical injury by scavenging reactive oxygen species [15].

Some of the coumarin derivatives formerly used as fixative and flavoring agents, are now regulated as food adulterants by the Food and Drug 
Administration (FDA) in the United States due to their adverse effects such as mild nausea, diarrhea, and hepatotoxicity when used in certain amounts [16-19]. Although currently marketed in several European countries, coumarin type drugs used for the treatment of lymphoedema, has not been approved for therapeutic purposes in the United States, due to their hepatotoxicity. However, recent discovery of coumarins having weak estrogenic activity resulted in the use of such derivatives as therapeutic agents in preventing the emergence of menopause related diseases, such as osteoporosis, increased risk for cardiovascular event / disease and cognitive deficiencies [20].

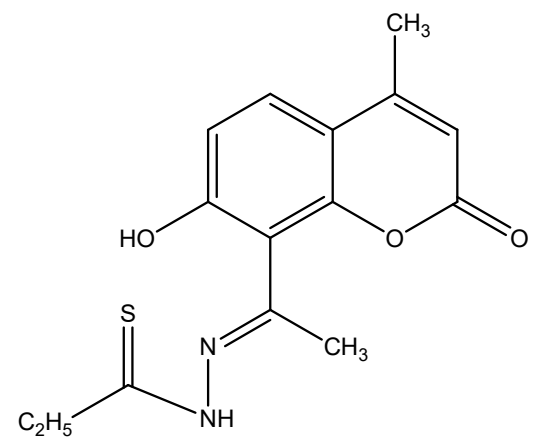<smiles>C/C(=N\NC(=S)Nc1ccccc1)c1c(O)ccc2c(C)cc(=O)oc12</smiles>

\section{Experimental}

In the present communication we present a study of two thiocoumarin derivatives namely (E)-1-(1-(7hydroxy-4-methyl-2-oxo-2H-chromen-8-yl) ethylene)-4-phenylthiosemicarbazide (I) and (E)N'-(1-(7-hydroxy-4-methyl-2-oxo-2H-chromen-8yl) ethylene) propanethiohydrazide

(II) Synthesized and purified according to the previously reported method [21] were kindly provided by prof. Dr. Mohamed Hussein of Cairo University. Chemicals were purchased from Sigma and Aldrich and were used without further purification. All solvents used in the study were of highest $\mathrm{o}$ available purity from Merck.

The electronic absorption spectra were recorded on Cary-400 UV-visible spectrophotometer connected to a Cary data acquisition system using $1 \mathrm{~cm}$ matched silica cells, while the fluorescence spectra were recorded by using Perkin- Elmer LS50B scanning spectrofluorophotometer. The temperature controller consists of a peltier element for heating and cooling, requisite amount of substrate and other reagents were transferred into the $1 \mathrm{~cm}$ fluorescence cell. The cell was placed in the cell holder and allowed to equilibrate thermally.

\section{Results and discussion}

3.1. Absorption and emission behavior of coumarin derivatives (I) and (II) in organic solvents.

The electronic absorption and emission spectra of 1 $\mathrm{x} 10^{-5} \mathrm{M}$ coumarin derivatives were measured at room temperature in different solvents of different polarities $(\Delta \mathrm{f})$ with $\mathrm{f}$ given by the relation [22]

$\Delta f=\frac{(\varepsilon-1)}{(2 \varepsilon+1)}-\frac{\left(n^{2}-1\right)}{\left(4 n^{2}+2\right)}$

Where $(\varepsilon)$ is the dielectric constant and $\mathrm{n}$ is the refractive index of the solvent. The absorption of coumarin is not affected by solvent polarity as shown in Table $(1,2)$, whereas the emission spectra are significantly influenced by the medium. With

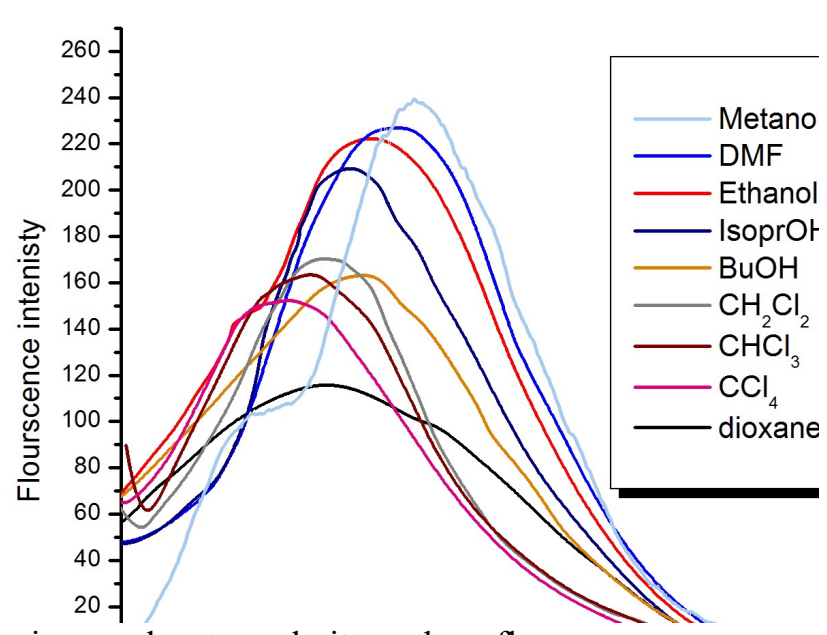

increasing solvent polarity, the fluorescence maximum is shifted to longer wavelengths from $395 \mathrm{~nm}$ in $\mathrm{CCl}_{4}(\Delta \mathrm{f}=0.115)$ to $450 \mathrm{~nm}$ in methanol $(\Delta \mathrm{f}=0.408)$, as shown in Figure $1(\mathrm{a}, \mathrm{b})$. 


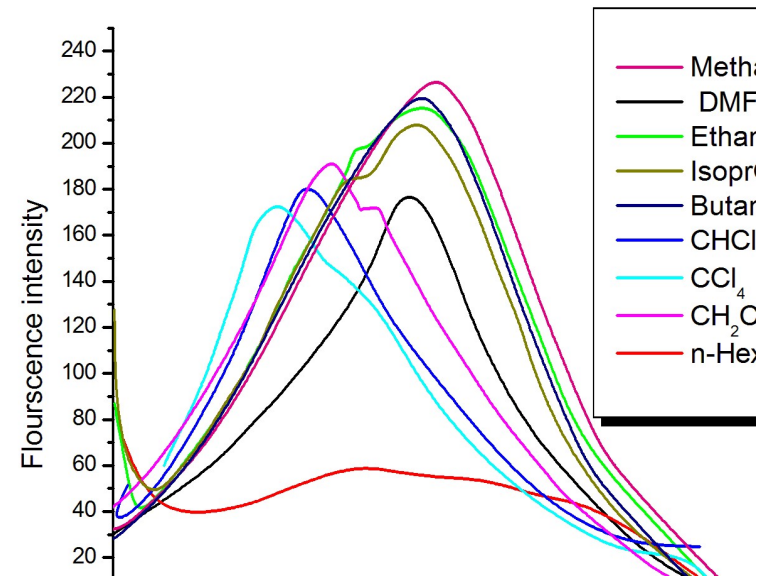

Figure (1). Fluorescence spectra of coumarine derivatives with different solvent polarities (a) coumarin I, (b) coumarin II

Table (1): Some spectral maxima and photo physical parameters of coumarin derivative (I) in different solvents.

\begin{tabular}{|c|c|c|c|c|c|c|c|}
\hline Solvents & $\begin{array}{c}\mathrm{E}_{\mathrm{T}}(30) \\
\mathrm{Kcal} / \mathrm{mol}\end{array}$ & $\begin{array}{l}\text { Dielectric } \\
\text { Constant }\end{array}$ & $\Delta f$ & $\begin{array}{c}\lambda_{\mathrm{f}} \\
(\mathrm{nm})\end{array}$ & $\begin{array}{c}\lambda_{\max (\mathrm{Abs})} \\
(\mathrm{nm})\end{array}$ & $\begin{array}{c}\varepsilon_{\max } \\
\mathrm{dm}^{3} \cdot \mathrm{mol}^{-1} \mathrm{~cm}^{-1}\end{array}$ & $\phi_{f}$ \\
\hline $\mathrm{CCl}_{4}$ & 32.4 & 2.24 & 0.115 & 409 & 308 & 15000 & 0.076 \\
\hline $\mathrm{CHCl}_{3}$ & 39.1 & 4.81 & 0.251 & 417 & 309 & 15320 & 0.086 \\
\hline $\mathrm{CH}_{2} \mathrm{Cl}_{2}$ & 40.7 & 9.08 & 0.319 & 425 & 309 & 15600 & 0.088 \\
\hline dioxan & 36 & 2.21 & 0.121 & 410 & 309 & 15150 & 0.079 \\
\hline DMF & 43.8 & 38.25 & 0.377 & 451 & 311 & 16150 & 0.099 \\
\hline $\mathrm{MeOH}$ & 55.4 & 32.6 & 0.393 & 455 & 312 & 16300 & 0.102 \\
\hline EtOH & 51.9 & 24.6 & 0.379 & 449 & 312 & 16000 & 0.099 \\
\hline IsoprOH & 49.2 & 18.3 & 0.367 & 443 & 312 & 15680 & 0.096 \\
\hline BuOH & 50.2 & 17.8 & 0.36 & 440 & 311 & 15400 & 0.087 \\
\hline
\end{tabular}

Table (2): Spectral maxima and photo physical parameters of coumarin derivative ( II) in different solvents.

\begin{tabular}{|r|c|c|c|c|c|c|c|}
\hline Solvents & $\mathrm{E}_{\mathrm{T}}(\mathbf{3 0})$ & $\begin{array}{c}\text { Dielectric } \\
\text { constant }\end{array}$ & $\begin{array}{c}\Delta \mathrm{f} \\
\mathrm{Kcal} / \mathrm{mol}\end{array}$ & $\begin{array}{c}\lambda_{\mathrm{f}} \\
(\mathbf{n m})\end{array}$ & $\begin{array}{c}\lambda_{\max (\mathrm{Abs})} \\
(\mathbf{n m})\end{array}$ & $\begin{array}{c}\varepsilon_{\max } \\
\mathbf{d m}^{3} \cdot \mathbf{m o l}^{-1} \mathbf{c m}^{-\mathbf{1}}\end{array}$ & \\
\hline $\mathrm{CCl}_{4}$ & 32.4 & 2.24 & 0.115 & 395 & 307 & 17400 & 0.065 \\
\hline $\mathrm{CHCl}_{3}$ & 39.1 & 4.81 & 0.251 & 408 & 306 & 18000 & 0.074 \\
\hline $\mathrm{CH}_{2} \mathrm{Cl}_{\mathbf{2}}$ & 40.7 & 9.08 & 0.319 & 418 & 307 & 18300 & 0.078 \\
\hline
\end{tabular}


For solvents with similar viscosities, a linear correlation exists between the solvent polarity $(\Delta \mathrm{f})$ and emission maximum $\left(\lambda_{\mathrm{f}} \max \right)$ as shown in

Figure (2)

3.2. Absorption and emission spectral behavior of coumarin derivatives in buffer solutions and estimation of $\mathrm{pKa}$ and $\mathrm{pKa}^{*}$

The electronic absorption spectra of coumarin derivatives were recorded in the presence of buffer solutions showing regular changes with isosbestic points as shown in Figure (4). In acid solutions, $\mathrm{pH}$ $=2$, the drugs exhibit bands around $320 \mathrm{~nm}$ and $309 \mathrm{~nm}$ for coumarin I and coumarin II respectively which may be due to ionization of $\mathrm{OH}$ group. upon increasing $\mathrm{pH}$ values the extinction coefficient decreases with spectral red shift. Further increase in $\mathrm{pH}$ values leads the ionization of $\mathrm{OH}$ group and new band characteristics to the anionic form appears at $367 \mathrm{~nm}$ and $565 \mathrm{~nm}$ for coumarins (I and II).

The fluorescence spectral bands for coumarin (I and II) increases in basic medium as shown in Figure (5) which may due to increasing formation of hydrogen bond in basic medium as well as modification of electronic transitions. According to half-height method and the modified limiting absorbance method the values of $\mathrm{pK}_{\mathrm{a}}$ and $\mathrm{pK}_{\mathrm{a}}{ }^{*}$ were determined. The data were collected in Table 3. Plots of the absorbance vs $\mathrm{pH}$ values gaves sigmoidal curves as shown in Figure 6 and 7 for coumarins (I and II), while the plots of $\mathrm{pH}$ vs $\log \frac{A-A_{\min }}{A_{\operatorname{man}}-A}$ gave linear relation (Figures 8 and 9)

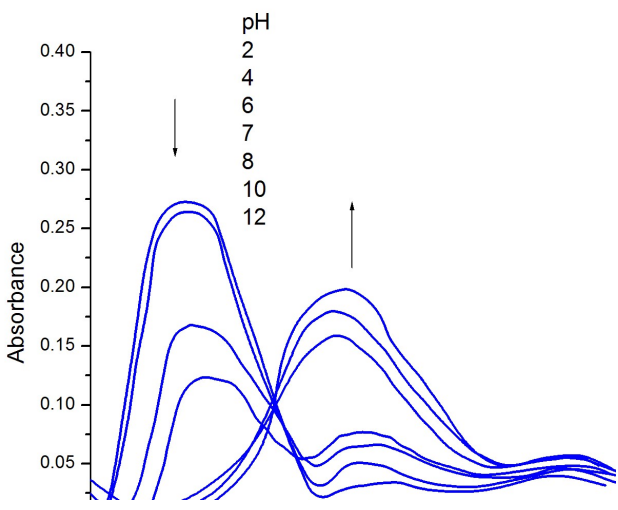

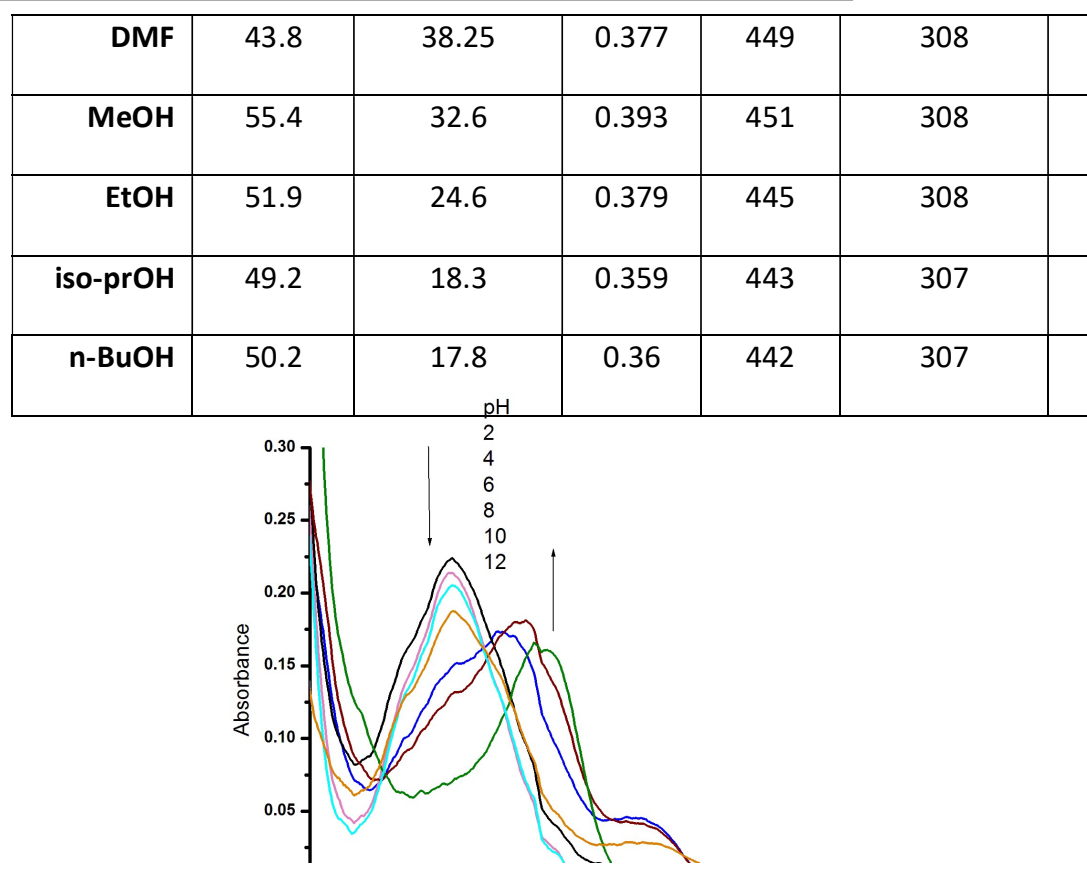

Figure(10). Fluorescence spectra of coumarin I (a) and coumarin II (b) in SDS solution. The emission intensities increase as the surfactant concentration increases.
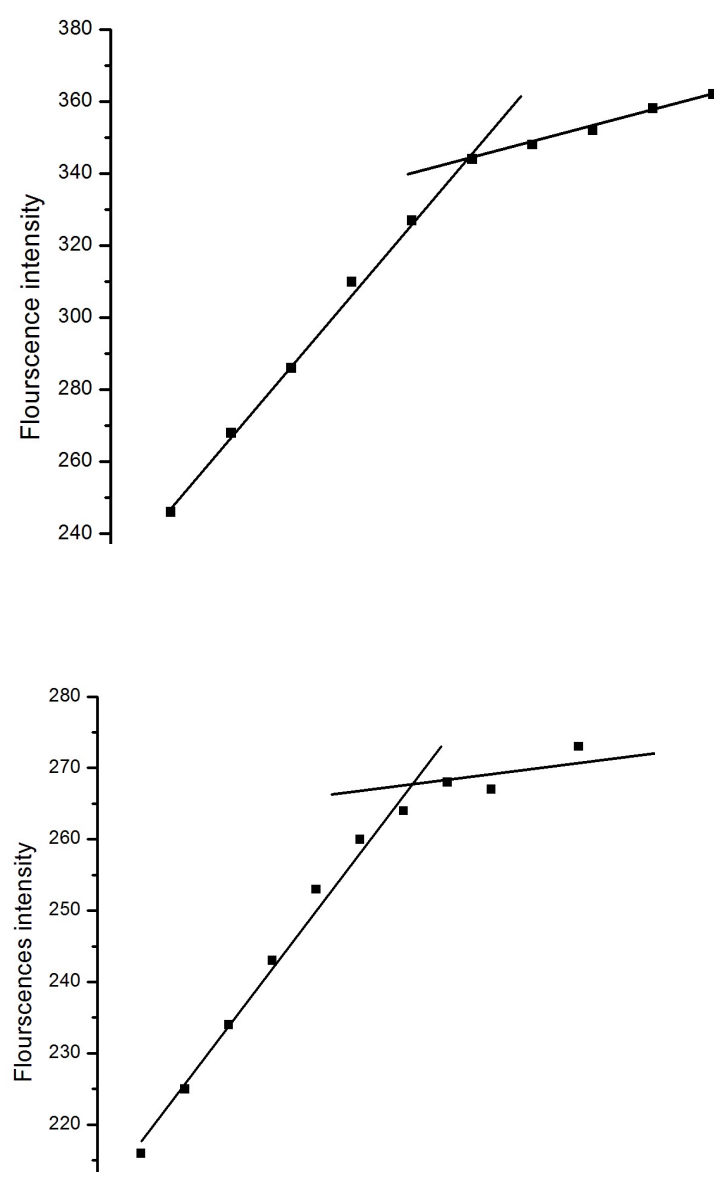
Figure (11). Plots of fluorescence intensity of coumarin derivatives vs SDS concentration,(a) Coumarin I and (b) coumarin II
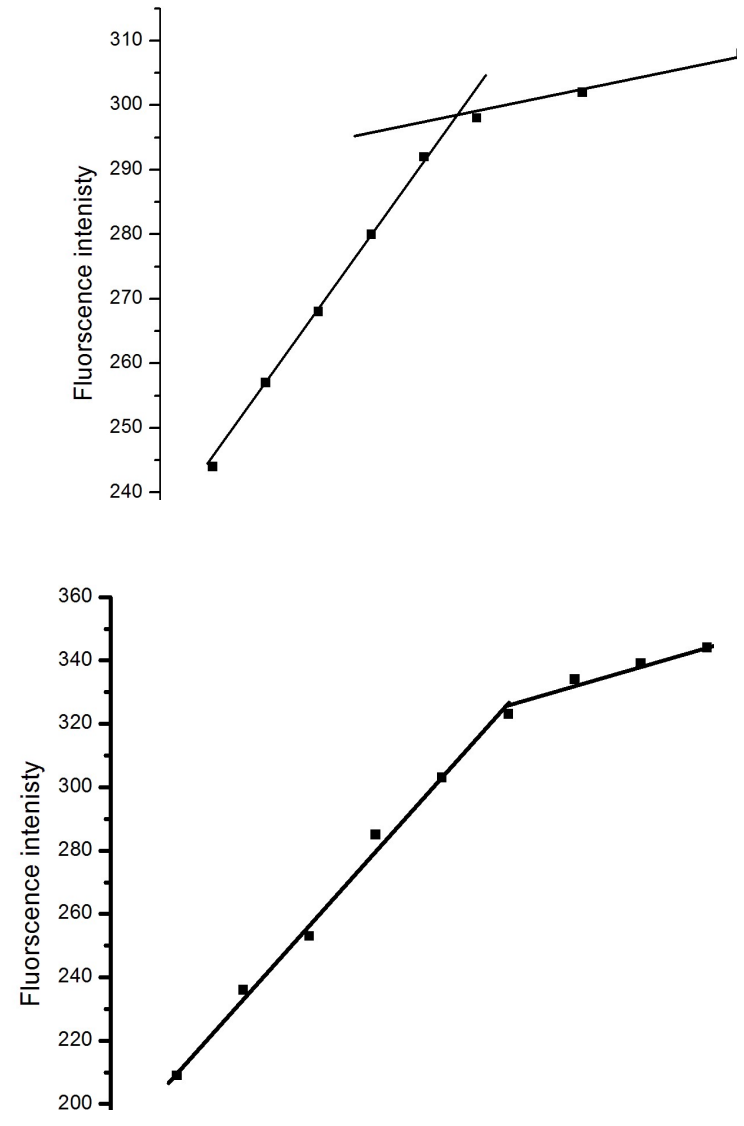

Figure (12). Plots of fluorescence intensity of coumarin derivatives vs CTAB concentration, (a) Coumarin I and (b) coumarin II.

\subsection{Quenching of fluorescence spectra using $\underline{\text { metal ions }}$}

The fluorescence quenching of coumarin derivatives (I and II) were studied using $\mathrm{Cu}^{+2}$ and $\mathrm{Co}^{+2}$ metal ions as quenchers in methanol. The fluorescence emission of coumarin derivatives (I and II) exhibits maxima at $450 \mathrm{~nm}$ and $455 \mathrm{~nm}$ for coumarin I and II respectively. As the concentration of the quencher $\left(\mathrm{Cu}^{+2}\right.$ or $\mathrm{Co}^{+2}$ metal ion) increases, the fluorescence intensities of derivatives I and II decrease as shown in Figures (13)

The Stern-Volmer plots of the quenching process of coumarin $\mathrm{I}$ and II emission using $\mathrm{Cu}^{+2}$ and $\mathrm{Co}^{+2}$ metal ions at different temperature are shown in Figures $(14,15$ and 16 ). The plots are linear and as the temperature increase the rate of quenching increases indicating that the quenching process is diffusion-controlled i.e. dynamic quenching mechanism. The energy of activation $\mathrm{Ea}$ was determined form Arrhenius equation as shown in Figures ((17, 18, and 19). The thermodynamic parameters for quenching process were calculated and tabulated in Tables (4 and 5). It was found that the energy of activation, $\Delta \mathrm{S}$ and $\Delta \mathrm{H}$ decreased in the following order $\mathrm{Co}^{+2}>\mathrm{Ni}^{+2}>\mathrm{Cu}^{+2}$ and the quenching rate increases from $\mathrm{Co}^{+2}<\mathrm{Ni}^{+2}<\mathrm{Cu}^{+2}$ this confirms that the quenching process is diffusion-controlled. Also quenching process for coumarin II is greater than coumarin I. This may be due to flexibility of aliphatic chain (ethyl group) in Coumarin II.
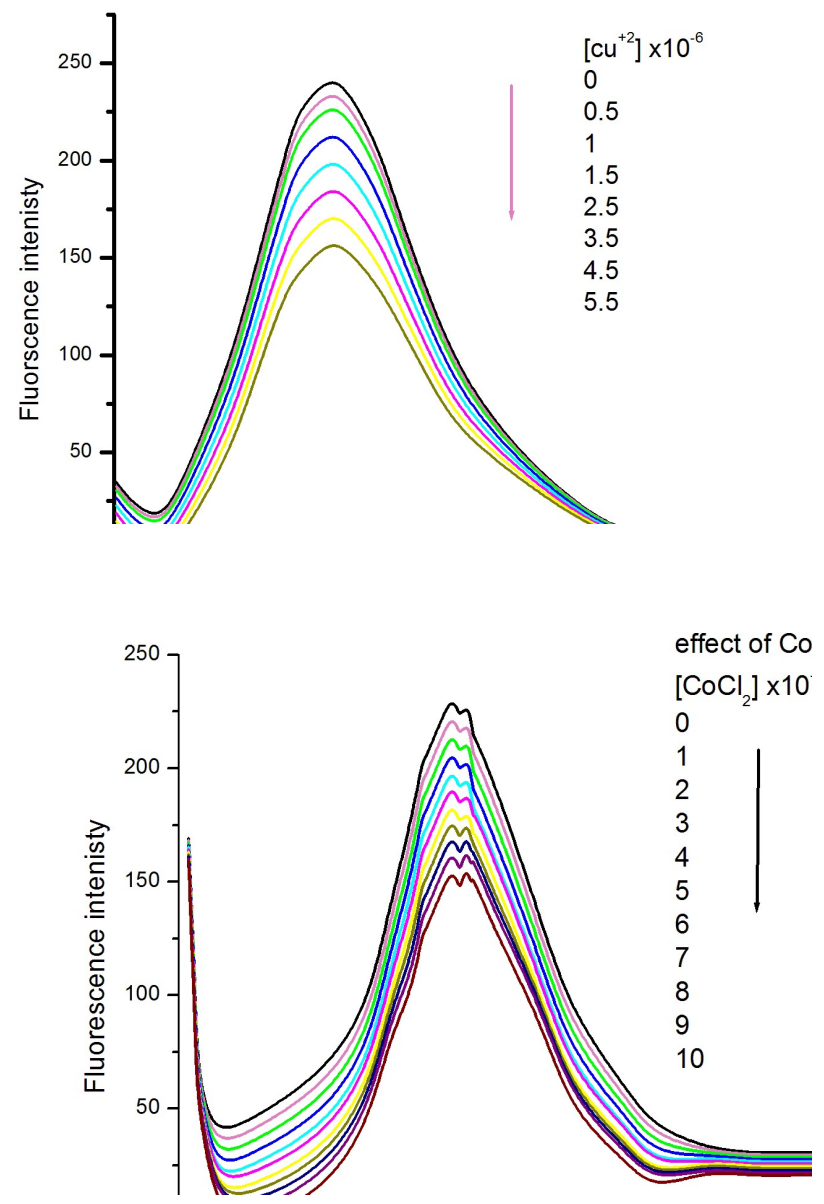
Figure (13). Fluorescence quenching of coumarin derivative (I) as a function of metal ion concentration
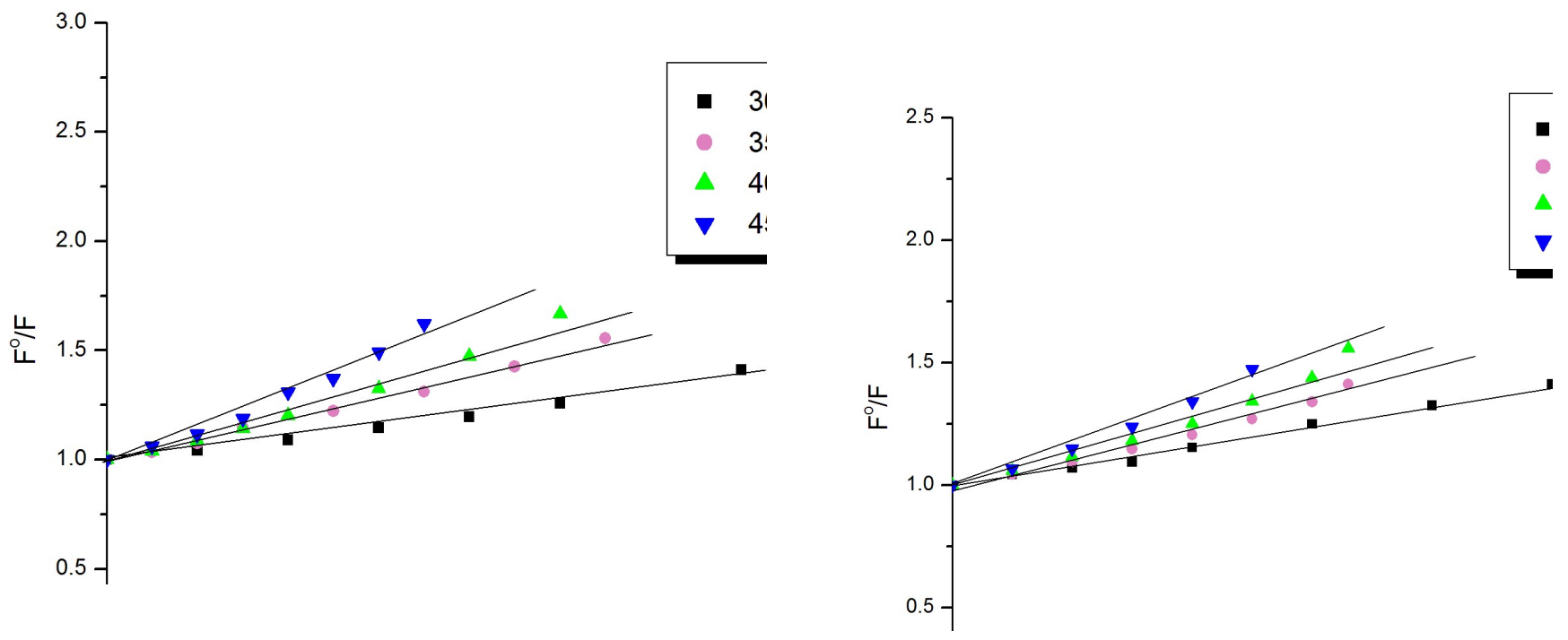

Figure (14). Stern-Volmer plots of the quenching of $1 \times 10^{-5} \mathrm{M}$ Coumarin by $\mathrm{Cu}^{+2}$ metal ions in methanol at different temperatures (a) Coumarin I and (b) Coumarin II

$$
\text { 4.0 }
$$

(a)

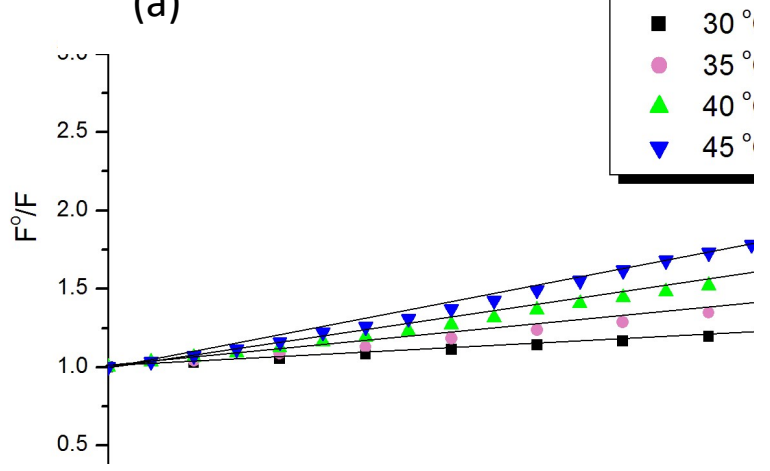

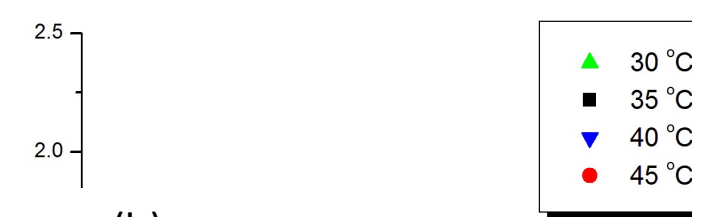

(b)

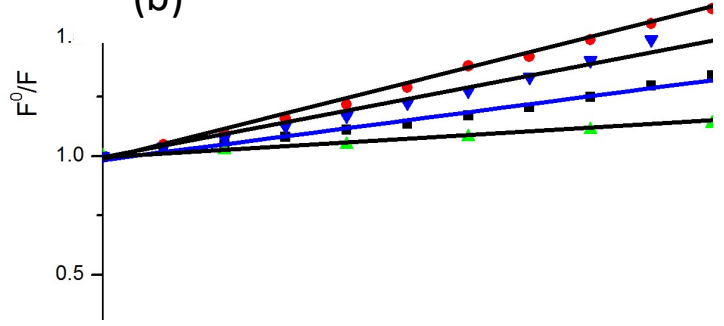

Figure (15). Stern-Volmer plots of the quenching of $1 \times 10^{-5} \mathrm{M}$ coumarin by $\mathrm{Ni}^{+2}$ metal ions in methanol at different temperatures (a) Coumarin I and (b) Coumarin II

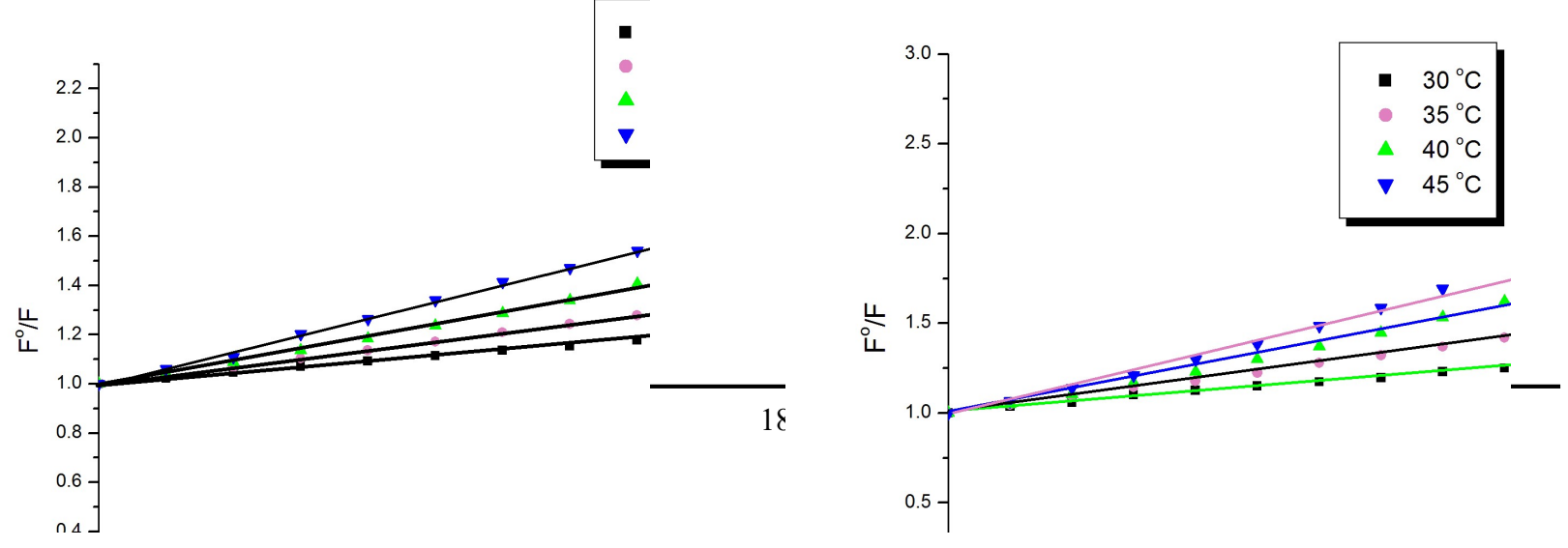


Figure (16). Stern-Volmer plots of the quenching of $1 \times 10^{-5} \mathrm{M}$ coumarins by $\mathrm{Co}^{+2}$ metal ions in methanol at different temperatures (a) coumarin I and (b) Coumarin II
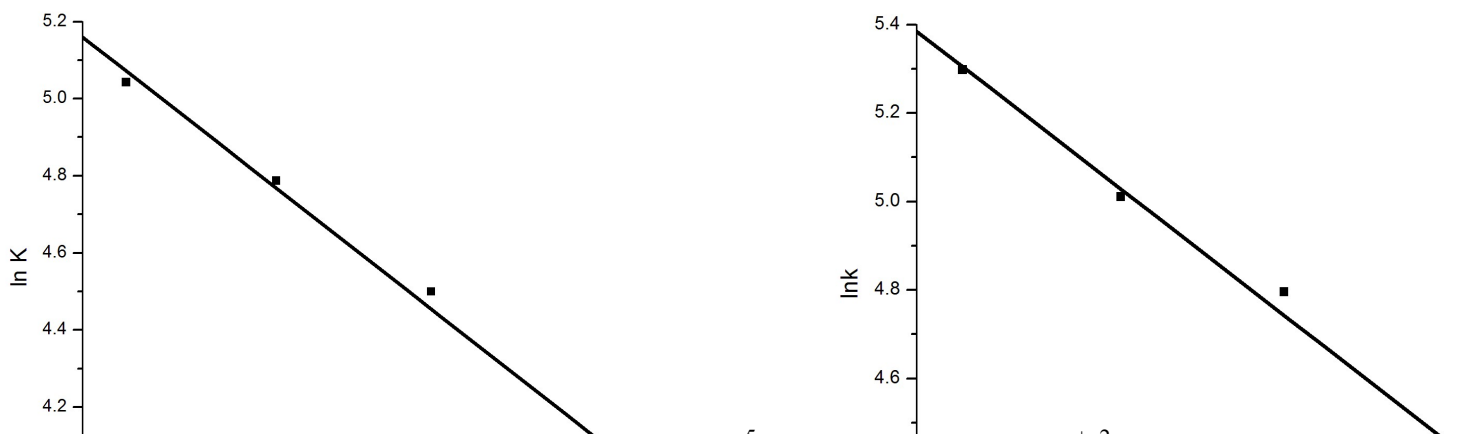

Figure (17). Arrhenius- plots of the quenching of $1 \times 10^{-5} \mathrm{M}$ coumatins by $\mathrm{Cu}^{+2}$ metal ions in methand at different temperatures (a) coumarin I and (b) Coumarin II

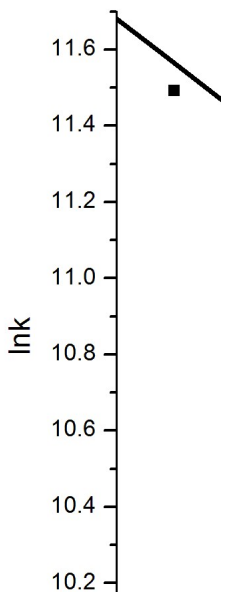

(a)

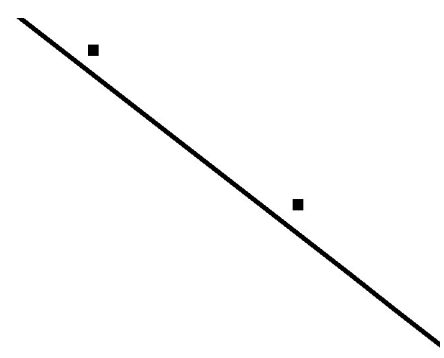

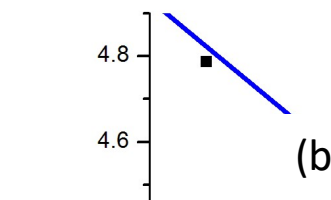

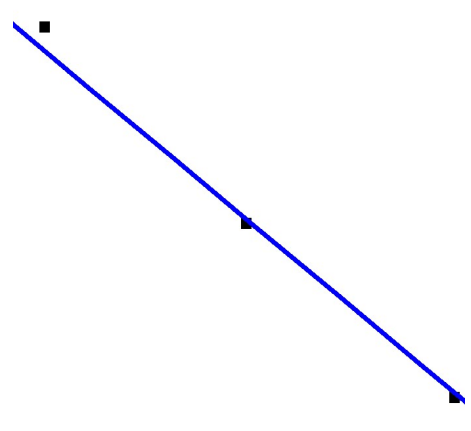

Figure (18). Arrhenius- plots of the quenching of $1 \times 10^{-5} \mathrm{M}$ coumarins by $\mathrm{Ni}^{+2}$ metal ions in methanol at different temperatures (a) coumarin I and (b) Coumarin II
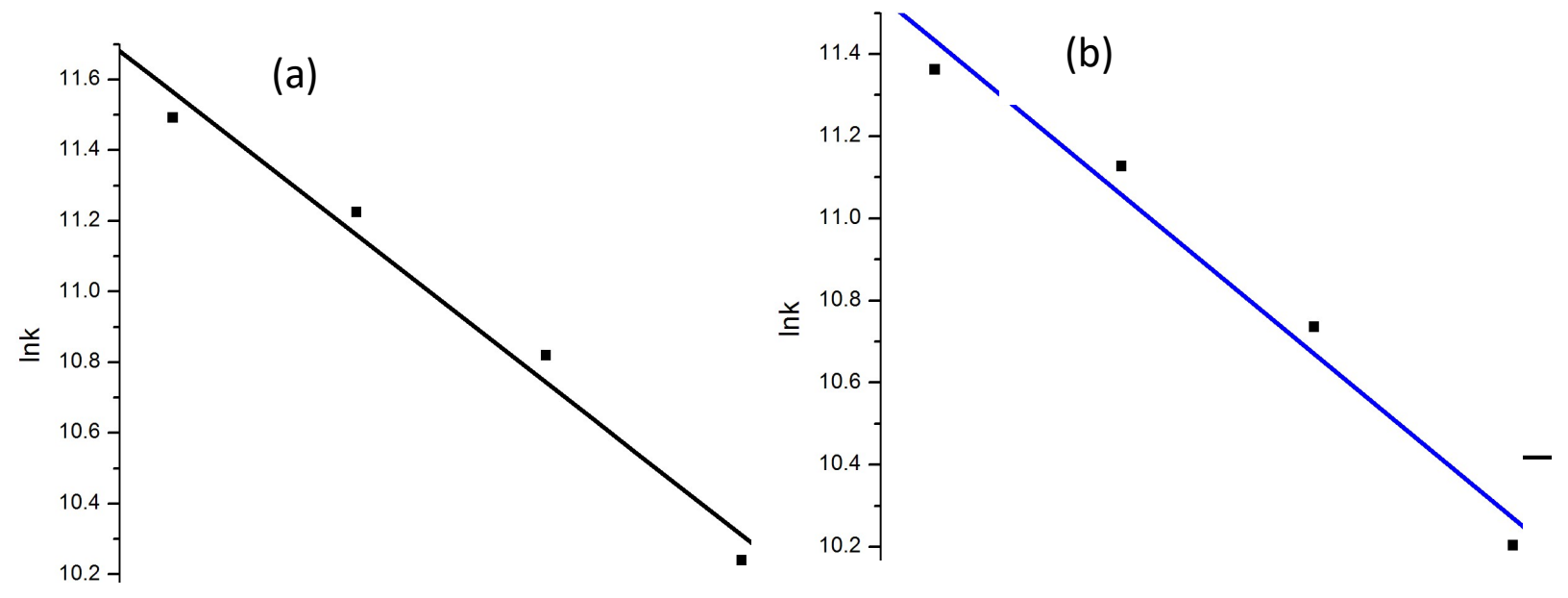
Figure (19). Arrhenius- plots of the quenching of $1 \times 10^{-5} \mathrm{M}$ coumarins by $\mathrm{Co}^{+2}$ metal ions in methanol at different temperatures (a) coumarin I and (b) coumarin II

Table. 4. Thermodynamic parameters for quenching $1 \times 10^{-5} \mathrm{M}$ coumarin I derivative using different metal ions at different temperatures

\begin{tabular}{|c|c|c|c|c|c|c|}
\hline Quecher & $\mathrm{T}(\mathrm{K})$ & $\begin{array}{l}\mathrm{K}_{\mathrm{SV}} \times 10^{6} \\
\mathrm{~kJ} / \text { mole }\end{array}$ & $\begin{array}{l}\mathrm{Ea} \\
\mathrm{kJ} / \text { mole }\end{array}$ & $\begin{array}{l}\Delta \mathrm{H}^{\#} \\
\mathrm{~kJ} / \text { mole }\end{array}$ & $\begin{array}{l}\Delta \mathrm{G}^{\#} \\
\mathrm{~kJ} / \text { mole }\end{array}$ & $\begin{array}{l}\Delta \mathrm{S}^{\#} \\
\mathrm{~J} / \text { mole } \mathrm{K}\end{array}$ \\
\hline \multirow{4}{*}{$\mathrm{Cu}^{+2}$} & 303 & 0.06 & \multirow{4}{*}{49.83} & \multirow{4}{*}{47.24} & \multirow{4}{*}{46.22} & \multirow{4}{*}{3.30} \\
\hline & 308 & 0.09 & & & & \\
\hline & 313 & 0.12 & & & & \\
\hline & 318 & 0.155 & & & & \\
\hline \multirow{4}{*}{$\mathrm{Ni}^{+2}$} & 303 & 0.032 & \multirow{4}{*}{59.76} & \multirow{4}{*}{57.20} & \multirow{4}{*}{47.72} & \multirow{4}{*}{30} \\
\hline & 308 & 0.050 & & & & \\
\hline & 313 & 0.075 & & & & \\
\hline & 318 & 0.098 & & & & \\
\hline \multirow{4}{*}{$\mathrm{Co}^{+2}$} & 303 & 0.021 & \multirow{4}{*}{63.00} & \multirow{4}{*}{60.44} & \multirow{4}{*}{48.70} & \multirow{4}{*}{38} \\
\hline & 308 & 0.034 & & & & \\
\hline & 313 & 0.050 & & & & \\
\hline & 318 & 0.069 & & & & \\
\hline
\end{tabular}

Table. 5. Thermodynamic parameters for quenching $1 \times 10^{-5} \mathrm{M}$ coumarin II derivatives using different metal ions at different temperatures

\begin{tabular}{|c|c|c|c|c|c|c|}
\hline Quecher & $\mathrm{T}(\mathrm{K})$ & $\begin{array}{l}\mathrm{K}_{\mathrm{SV}} \times 10^{6} \\
\mathrm{~kJ} / \text { mole }\end{array}$ & $\begin{array}{l}\mathrm{Ea} \\
\mathrm{kJ} / \text { mole }\end{array}$ & $\begin{array}{l}\Delta \mathrm{H}^{\#} \\
\mathrm{~kJ} / \text { mole }\end{array}$ & $\begin{array}{l}\Delta \mathrm{G}^{\#} \\
\mathrm{~kJ} / \mathrm{mole}\end{array}$ & $\begin{array}{l}\Delta \mathrm{S}^{\#} \\
\mathrm{~J} / \text { mole.K}\end{array}$ \\
\hline \multirow{4}{*}{$\mathrm{Cu}^{+2}$} & 303 & 0.083 & \multirow{4}{*}{45.65} & \multirow{4}{*}{43.09} & \multirow{4}{*}{45.46} & \multirow{4}{*}{-28} \\
\hline & 308 & 0.121 & & & & \\
\hline & 313 & 0.160 & & & & \\
\hline & 318 & 0.200 & & & & \\
\hline \multirow{4}{*}{$\mathrm{Ni}^{+2}$} & 303 & 0.043 & \multirow{4}{*}{56.44} & \multirow{4}{*}{53.88} & \multirow{4}{*}{47.39} & \multirow{4}{*}{21} \\
\hline & 308 & 0.057 & & & & \\
\hline & 313 & 0.090 & & & & \\
\hline & 318 & 0.12 & & & & \\
\hline
\end{tabular}




\begin{tabular}{|l|l|l|l|l|l|l|}
\hline \multirow{4}{*}{$\mathrm{Co}^{+2}$} & 303 & 0.027 & \multirow{4}{*}{60.40} & \multirow{2}{*}{57.84} & \multirow{2}{*}{47.94} & 32 \\
\cline { 2 - 3 } & 308 & 0.046 & & & \\
\cline { 2 - 3 } & 313 & 0.068 & & & & \\
\cline { 2 - 3 } & 318 & 0.086 & & & & \\
\hline
\end{tabular}

\section{Conclusion}

The absorption spectra of Coumarin aer not affected by solvent polarity, whereas the emission spectra are significantly influenced by the medium. This indicates a more polar excited state leading to more salvation of excited states compared with ground states. the fluorescence quantum yield is increased with increasing the solvent polarity and the maximum emission wavelength is shifted to longer wavelengths (red shifted) due to stabilization of excited state in polar solvent due to formation hydrogen bond. This was confirmed by the effect of buffer solution, where in basic medium the maximum emission wavelength is shifted to longer wavelength and the fluorescence quantum yield is increased in alkaline medium, $\mathrm{pk}_{\mathrm{a}}$ and $\mathrm{pk}_{\mathrm{a}} *$ are determined.

The emission intensity of coumarin I and II increased as the surfactant concentration increases with a break at surfactant concentrations which are very close to the critical micelle concentration of SDS and CTAB, due to frictional forces and decreasing of solvent-free volume required for free rotation which are responsible fluorescence quenching. The fluorescence quenching of coumarin derivatives (I and II) was studied using $\mathrm{Cu}^{+2}, \mathrm{Ni}^{+2}$ and $\mathrm{Co}^{+2}$ metal ions at different temperatures. The rate of quenching $\mathrm{K}_{\mathrm{SV}}$ increases in linear correlation with increasing the temperature, indicating that the quenching process is diffusion-controlled i.e. dynamic quenching mechanism and the thermodynamic parameters confirm this mechanism.

\section{References:}

- $\quad$ Egan D, O'Kennedy R, Moran E, Cox D, Prosser E, Thornes RD. Drug Metab. Rev.;22:503.(1990). [PubMed]

- Borges F, Roleira F, Milhazes N, Santana L, Uriarte E. Curr. Med. Chem.;12:887. (2005). [PubMed]

- Murray RDH, Mendez J, Brown SA. The Natural Coumarins: Occurrence, Chemistry and Biochemistry. New York: Wiley; (1982).
- $\quad$ Lacy A, O'Kennedy R. Curr. Pharm. Des.; 10:3797. (2004). [PubMed]

- Gottlieb OR, Herrmann K, Murray RDH, Ohloff G, Pattenden G. Progress in the Chemistry of Organic Natural Products. New York: Springer-Verlag; (1978).

- Harvey RG, Cortex C, Ananthanarayan TP, Schmolka S. J. Org. Chem.;53:3936. (1988).

- Kostova I, Raleva S, Genova P, Argirova R. Bioinorg. Chem. Appl.:68274. (2006). [PMC free article] [PubMed.]

- Moffet RS. J. Med. Chem.; 7:446. [PubMed].

(1964)

Al-Haiza MA, Mostafa MS, El-Kady MY. Molecules.; 8:275. (2003).

- Musiciki B, Periers AM, Laurin P, Ferroud D, Benedetti Y, Lachaud S, Chatreaux F, Haesslein JL, LLtis A, Pierre C, Khider J, Tessol N, Airault M, Demassey J, Dupuis-Hamelin C, Lassaigne P, Bonnefoy A, Vicat P, Klich M. Bioorg. Med. Chem. Lett.;10:1695. (2000). [PubMed]

- Fylaktakidou KC, Hadipavlou-Litina DJ, Litinas KE, Nicolaides DN. Curr. Pharm. Des.;10:3813.( 2004). [PubMed]

- Jung J, Kin J, Park OS. Synth. Commun.;31:1195.(2001).

- Wang Z, Hara K, Dan-oh Y, Kasada C, Shinpo A, Suga S, Arakawa H, Sugihara H. J. Phys. Chem. B.;109:3907.( 2005). [PubMed]

- Madhavan GR, Balraju V, Malleshasm B, Chakrabarti R, Lohray VB. Bioorg. Med. Chem. Lett.;13:2547.( 2003). [PubMed]

- Paya M, Halliwell B, Hoult JR. Biochem. Pharmacol.;44:205.( 1992). [PubMed]

- Casley-Smith JR, Morgan RG, Piller NB. N. Engl. J. Med.;76:1158. (1993). [PubMed]

- Casley-Smith JR, Casley-Smith JR. Med. J. Aus.;162:391.( 1995). [PubMed]

- $\quad$ Beinssen AP. Med. J. Aus.;167:725.( 1994).

- Cox D, O’Kennedy R, Thornes RD. Hum. Toxicol.; 8:501.1989 [PubMed] 
- Usui T. Endocrine J.;53:7.( 2006). [PubMed]

- Hussein MM. Synthesis, photosensitivity and antimicrobial studies on coumarin Thiosemicarbazone. Az J pharm Sci 39;28698,(2009).

- Atvars TDZ, Bortolato CA, Bruneli DD. J Photochem Photobiol;A68:41.(1991)

- $\quad$ Shim SC, Kim MS, Lee KT, Lee BH. J Photochem Photobiol; A 67:23.( 1992).

- Fayed TA, El-Daly SA, Etaiw SH. J Photochem Photobiol; A121: 183.( 1999).
- Al- Hazmy SM, Kassab KN, El-Daly SA, Ebeid EM. J Spectrochim Acta A56:1773.( 2000).

- Scaiano J.S. CRC Handbook of Organic Photochemistry, press, Inc, Boca Raton, Florida, P. 402.(1989).

- Gaber .M, Fayed T.A. El-Daly SA., El-Sayed Y.A. Photochem Photobiol. Sci.7.257. (2008).

$$
\text { الملخص العربى }
$$

السلوك الفوتوفيزيقي والفوتوكيميائي لبعض مشتقات الكومارين

$$
\text { أ.د/ محمد يسري الشيخ , أ. د/ صالح عبد العظيم عطيه, د / علي كامل ابو سيف, إيهاب عبد القوي تاج الدين }
$$

\section{قسم الكيمياء- كلية العلوم- جامعة طنطا}

$$
\begin{aligned}
& \text { مشتقات الكومارين من الاصباغ الهامه و التي تستخدم في مجالات علميه وتكنولوجيه عديده , فهي تستخدم علي نطاق و اسع لبناء مجموعات } \\
& \text { منتو عه من المو اد ذات الوميض الضوئي والحساسية الكيميائيه. ولهذه المشتقات الكثير من الاستخدامات في مجال الطب والهي والدو اء فتستخدم كمانع }
\end{aligned}
$$

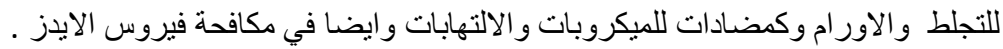

$$
\begin{aligned}
& \text { في هذا البحث تم در اسه السلوك الفوتوفيزيقي والفونوكيميائي لمركبيين من مشتقات الكومارين حيث وجد ان طيف الامتصاص لا يتاثر بقطبية } \\
& \text { المذيب في حين ينأثر طيف الانبعاث بقطبية المذيب, وبزياده قطبية المذيب يزداد الناتج الفلورسيني الضوئي ( }
\end{aligned}
$$

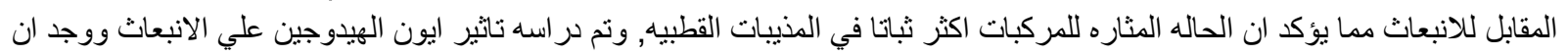

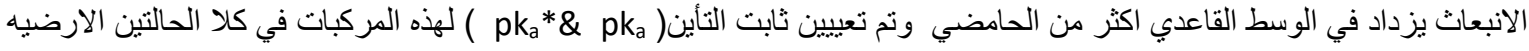

$$
\begin{aligned}
& \text { و المثاره . } \\
& \text { كما تم در اسه ناثير المواد ذات النثاط السطحي مثل الدوديسيل سلفات و سيتيل ثلاثي ميثيل الامونيوم بروميد علي الانبعاث الفلورسيني الضوئي } \\
& \text { ( ) و و جد ان زياده تركيز المواد ذات النشاط السطحي يؤدي الي زيادة الناتج الضوئي ( } \\
& \text { كما تم در اسه تاثير ايونات بعض المعادن علي الانبعاث الفلورسني الضوئي ( } \\
& \text { الانبعاث الفلوروسيني ( }
\end{aligned}
$$

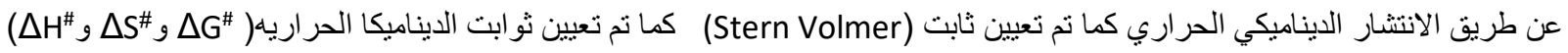

$$
\begin{aligned}
& \text { التي تؤكد هذه المكانيكيه ( الانتشار الديناميكي الحراري) . }
\end{aligned}
$$

